\title{
Adipose Tissue and Atherosclerosis
}

\author{
R. POLEDNE ${ }^{1}$, I. KRÁLOVÁ LESNÁ ${ }^{1}$, S. ČEJKOVÁ ${ }^{1}$ \\ ${ }^{1}$ Laboratory for Atherosclerosis Research, Centre of Experimental Medicine, Institute for Clinical \\ and Experimental Medicine, Prague, Czech Republic
}

Received July 17, 2015

Accepted July 31, 2015

\begin{abstract}
Summary
High-energy intake which exceeds energy expenditure leads to the accumulation of triglycerides in adipose tissue, predominantly in large-size adipocytes. This metabolic shift, which drives the liver to produce atherogenic dyslipidemia, is well documented. In addition, an increasing amount of monocytes/macrophages, predominantly the proinflammatory M1-type, cumulates in ectopic adipose tissue. The mechanism of this process, the turnover of macrophages in adipose tissue and their direct atherogenic effects all remain to be analyzed.
\end{abstract}

\section{Key words}

Adipose tissue $\bullet$ Dyslipidemia $\bullet$ Inflammation $\bullet$ Macrophages

\section{Corresponding author}

R. Poledne, Laboratory for Atherosclerosis Research, Centre of Experimental Medicine, Institute for Clinical and Experimental Medicine (IKEM), Videnska 1958/9, 14021 Prague 4, Czech Republic. E-mail: rudolf.poledne@ikem.cz

\section{Adipose tissue and dyslipidemia}

For a long time it has been evident that adipose tissue is a store of energy reserved for acute needs during inadequate energy intake. Numerous reviews describe the disease known as "adiposopathy" as the consequences of obesity (Bays 2011). High-density energy in adipocyte triglycerides is a very suitable energy substrate and free fatty acids (FFA) released by hormone-sensitive lipase (Zimmerman et al. 2009) are an immediate emergency source of energy in the beta-oxidation of muscle and hepatic mitochondria. During long time development of men this energy source was principal question of life and death contrary to recent situation when we are not in the real fasting status.

A disequilibrium between high-energy intake and low expenditure leads to adipose tissue accumulation, which in a work from more than 70 years ago was found to be connected to cardiovascular disease (Vague 1947). The accumulation of triglycerides (TG) in ectopic fat is now considered most likely its main cause and the most frequent pathology in men. Insulin deficiency is a key player in what is known as "metabolic syndrome", first described in detail two decades ago (Reaven 1994). Consequently, hormone-sensitive lipase is inadequately inhibited in adipose tissue during postprandial status (Shulman 2014). FFA is released into circulation, unused for energy production and the excess of which are fished out in the liver. Hepatocytes are then able to store them in the form of depot TGs (Donnelly et al. 2005). This produces a special type of fat vacuole in hepatocytes, which can develop into non-alcoholic liver steatosis (Cohen et al. 2011). Currently, it is probably the most frequent pathology in industrialized countries (but probably also in some developing countries of the Middle East and India). Hepatocytes try to counteract TG accumulation by accelerating intracellular TG transport in the form of very low-density lipoproteins (VLDL) and secreting them into circulation (Adiels et al. 2006). These types of VLDLs possess a much higher TG content (calculated for one molecule carrier of apoprotein B), they possess also an increased relationship of TG to cholesterol esters and are consequently a much poorer substrate for lipoprotein lipase on the surface of endothelial cells. This enzyme is responsible for splitting TG VLDL particles (as well as chylomicrons) and their 
consequent change to low density lipoproteins (LDL). TG-rich VLDLs and their remnants are accumulated in circulation, which increases TG concentration in the fasting status, but namely the postprandial status. They are also believed to be atherogenic over a long period. Recent large epidemiological studies have been able to confirm their atherogenic effect (Langsted et al. 2011). The atherogenic effect of remnant lipoproteins produced by slower lipolysis of TG in TG-rich VLDLs is accompanied by a decreased rate of LDL production (Boren et al. 2014). These "small dense LDL particles" are substantially pro-atherogenic, since their entrance into the arterial wall is easier, and may also display a high probability of oxidation.

This type of typical dyslipidemia, which is prevalent in "rich" societies, is very frequently combined with insulin resistance and liver steatosis, but primarily with the enlargement of visceral adipose tissue, which produces large TG-rich VLDLs (DiPietro et al. 1999). The primary reason for these metabolic pathways is the accumulation of TG in adipose tissue, which produces very large adipocytes. This phenotype of large adipocytes and dyslipidemia is combined with chronic proinflammatory status, decreased sensitivity to insulin (Xu et al. 2003) and, consequently, liver steatosis and TG accumulation in hepatocytes. The main reason for proinflammatory status is the conclusive changes in adipose tissue, as documented recently. Although hepatocytes and muscle cells also exhibit obesity-induced proinflammatory status (Shulman 2014), white adipose tissue plays a key role in the development of proinflammatory status.

\section{A new role of adipose tissue}

A new role of adipose tissue was described more than two decades ago. Firstly, a new role of leptin, as a hormone that affects appetite and individual hunger feelings, was described (Liuzzi et al. 1999). Later it was documented that adipocytes produce a number of molecules among them interleukin 6 and tumor necrosis factor $\alpha$ - two cytokines which stimulate proinflammatory status of the whole organism. It is now well known that adipose tissue produces more than 50 cytokines and hormones (Kershaw and Flier 2004) as well as signal molecules (adipokines). These have either an autocrine or paracrine function, which affect numerous processes related to energy homeostasis, glucose metabolism but also immune reaction.
This is one part of proinflammatory activity of adipose tissue related to the activity of adipocytes. Adipose tissue contains large amounts of white line cells in addition to adipocytes, which enter and leave adipose tissue continuously and represents the second part of proinflammatory effect. A certain proportion of monocytes/macrophages $(\mathrm{MO} / \mathrm{M} \varphi)$ are always present within adipose tissue, but their number increases after the effect of numerous pathophysiological stimuli on lipid metabolism. An increased amount of $\mathrm{MO} / \mathrm{M} \varphi$ in white adipose tissue is also produced by the short-term feeding of a TG-rich diet. In any case, the amount of these cells is increased in chronic over-nutrition when the normal physiological capacity of adipocytes is exceeded, which progresses to an unusually large amount of adipocytes leading to stress and cellular dysfunction (Ogedaard et al. 2007). The reasons for an excess of physiological homeostasis of adipocytes and the development of unusually large adipocytes after high FFA inflow are still not known. One possible reason discovered recently (Ferranter 2013) is associated with their individual ability to buffer high FFA inflow. Via their scavenger function, these cells are able to absorb a shock of FFA inflow in postprandial status, changing to proinflammatory status when the buffer capacity is permanently crossed over (namely in insulin inadequate/lower sensitivity).

This buffering capacity of $\mathrm{MO} / \mathrm{M} \varphi$ depends not only on the presence of these molecules in adipose tissue, but namely on their absolute number and ratio to adipocyte mass. The proportion of $\mathrm{MO} / \mathrm{M} \varphi$ cells in adipose tissue normally reach several percent under physiological conditions, but can reach a ratio of 1:1 for obesity and for a maximal size of adipocytes. Therefore, in long-term obese individuals, $\mathrm{MO} / \mathrm{M} \varphi$ represents $50 \%$ of all cells of white adipose tissue.

\section{Heterogeneity of macrophages}

The family of $\mathrm{MO} / \mathrm{M} \varphi$ in adipose tissue is very non-homogenous as well as in other pathological statuses. Besides normally stimulated proinflammatory macrophages, named M1, anti-inflammatory alternatively stimulated M2 macrophages are also present, which do not produce inflammatory adipokines (Italiani and Boraschi 2014). In adipose tissue of lean experimental animals, anti-inflammatory M2 cells are predominantly presented (Lumeng et al. 2007), whereas obesity induced by a high-fat diet drives adipose tissue to cumulate proinflammatory M1 macrophages (Weisberg et al. 
2003). Differentiation between these two statuses has been generally accepted and discussed in the recent literature. However, a concrete phenotype description of M1 and M2 cells based on a definition of different surface markers is rather unclear. Classically activated M1 macrophages are stimulated by interferon gamma (IFN $\gamma$ ) produced by Th1 cells. They predominantly express phagocytic activity and represent a natural defense against bacterial and parasitic infections (Stöger et al. 2010). These phagocytising cells produce a large number of proinflammatory cytokines, such as tumor necrosis factor (TNF $\alpha$ ), Il-13 and Il-18 (Martinez et al. 2008) and are potentially proatherogenic. In contrast, anti-inflammatory M2 macrophages are stimulated by the product of Th2 cells (Il-3 and Il-14) and have a buffering effect during long lasting chronic infections. Although a phenotype differentiation between M1 and M2 macrophages has not been resolved, it has been documented that M1 macrophages mainly produce NO, whereas M2 macrophages mainly produce ornithine as a final metabolite of arginine in two different pathways. Recent studies (Mills 2012) have gone so far as to propose that the ratio of M1/M2 macrophages might play a pivotal role in the most frequent pathologies (cancer and atherosclerosis) and is able to influence the average length of life in men. In contrast to external antigens (in typical infection diseases), the M1/M2 ratio plays the main role in these two pathologies. This ratio works in synchronicity with a number of Th1 and Th2 cells and indicates a status known as "innate immunity".

Research in this field has enlarged substantially in the last number of years and the number of related publications has risen in geometric order. The main parts of these in vitro studies analyze several different regulations for proinflammatory factors (which also include the nutritional effect of saturated fatty acids). However, an exact definition of the phenotype of phagocytising M1 and anti-inflammatory effective M2 is not still clear. Expression of M1 and M2 has been used in numerous review articles related to this problem without, however, correctly defining both phenotypes (Stöger et al. 2010, Mallat 2014, Suganami and Ogawa 2010). It is also very probable that adipose tissue also contains another phenotype between M1 and M2 (Stöger et al. 2010) and may be presented in actual non-stationary situations with the possibility of one phenotype being changed to another (Mallat 2014). It is still not clear how an inflow of macrophages into adipose tissue changes the acute amount of macrophages on the one side or if an outflow of these cells (after a certain residential period) from the tissue is more important. It has been proposed that all tissue-resident macrophages are fully differentiated (Taylor et al. 2005), but it has been documented recently (Mulder et al. 2014) that spleenderived macrophages are readily polarized to M1 and M2 under different external influences. It might be proposed that macrophages which release adipose tissue after a certain residence period possess more proinflammatory phenotypes compared to cells that enter the tissue from circulation. Then these macrophages might translate proinflammatory signals to other organs, namely the arterial wall.

\section{Macrophages and the arterial wall}

A central role of $\mathrm{MO} / \mathrm{M} \varphi$ in atherogenesis was first described in the pioneering work of Goldstein and Brown (Goldstein and Brown 1987), founders of the theory of plasma cholesterol regulation due to specific apoB receptors. This laboratory also described scavenger receptors for apoB containing particles on the surface of macrophages (Brown and Goldstein 1983). These receptor macrophages clean the subendothelial space of large and medium size arteries from abundant LDL particles and are able to maintain the physiological equilibrium of the arterial wall between the actual needs of the cholesterol molecule on the one hand and the adequate or in-adequate inflow of LDL-carrying particles in hypercholesterolemia on the other. It has been accepted for quite some time that in addition to lipid disorders, inflammation and the central role of macrophages are an integral part of atherosclerosis pathology (Lohmann et al. 2009).

Adipose tissue and, especially, obese adipose tissue influence the adhesion of monocytes (and other immune-competent cells) to endothelial cells and their migration to the arterial wall. Adipose tissue is composed of not only adipocytes, but also a number of other cell types such as fibroblasts, endothelial cells, immunocompetent cells and many others. But adipocytes are the main producers of adipokines (leptin, adiponectin, resistin, visfatin, etc.), a subtype of the cytokine family. The adipokines produced in adipocytes stimulate production of adhesion molecules (mainly intercellular adhesion molecule ICAM-1, vascular cell adhesion molecule VCAM-1), which in turn increases the adhesion of monocytes to the endothelium (Kawanami et al. 2004, Manuel-Apolinar et al. 2013, Mattu and Randeva 2013). 
These cells can up-regulate various mediators of vascular inflammation like TNF $\alpha$, IL2, IL6 and macrophage chemotactic protein MCP-1 from endothelial cells and peripheral blood mononuclear cells (Bouloumie et al. 1999). Adiponectin, which is also produced by adipose tissue, plays the opposite role. It is considered an antiatherogenic adipokine, which is produced in lower amounts in obese subjects and influences eNOS (Adya et al. 2015). Generally, chronic inflammation and adipose tissue metabolic dysfunction (e.g. higher production of proinflammatory factors or soluble adhesion molecules) influence the endothelium and increase its adhesiveness to monocytes.

Trapping of macrophages in the subendothelium of the vascular wall is influenced by a number of proteins produced by macrophages themselves. One of these factors is macrophage colony stimulated factor (MCSF) and macrophage chemotactic factor (MCF) with similar effect. Activation of macrophages as a result of their atherogenic function is induced by interferon gamma (IFN $\gamma$ ) produced by Th1 cells (Gupta et al. 1997). Increased production of these molecules traps macrophages in the interstitial space between smooth muscle cells. Consequent to this process, residential macrophages appear and further develop as foam cells. Also, several surface receptors on macrophages are able to influence mobility of these molecules in the subendothelium. Post-translation glycosylation of one of these receptors (CcR5) substantially stimulates atherogenesis (Scott et al. 2012). In contrast, a decrease of glycosylation inhibits atherogenesis in genetically modified knock-out mice for this protein (Cambadiere et al. 2008). Similarly, surface receptor $\mathrm{Cx} 3 \mathrm{cr}$ on platelets influences macrophage differentiation and is also stimulated by hypercholesterolemia (Cambadiere et al. 2008). This represents a new mechanism of trapping macrophages in the arterial wall (Postea et al. 2012). Recently, a new macrophage-producing protein, netrine1, has been described (Van Gills et al. 2012). It is of interest that its expression in macrophages is stimulated intracellularly by saturated fatty acids. This might indicate an additional atherogenic effect of SAFA in addition to their well-known influence on hypercholesterolemia.

Differentiation of monocytes to macrophages and then to residential macrophages within the subendothelial space of the arteries is a central process of atherogenesis and is regulated by a number of transcription factors. One of the important factors of differentiation is caveolin (a structural protein of intracellular caveloae), which stimulates transcription of several proinflammatory mediators and surface receptors of macrophages (Fu et al. 2012). It also stimulates synthesis of CD36 on the macrophage surface. This receptor is stimulated at the same time by oxidized LDL (Park et al. 2009) leading to the acceleration of atherogenesis through a combination of environmental effects (high intake of alimentary saturated fat) on stimulated proinflammatory macrophages as well as hypercholesterolemia.

\section{Development of macrophages into foam cells}

Differentiation of $\mathrm{MO} / \mathrm{M} \varphi$ is always combined with phagocytic activity, so it is understandable that production of foam cells is substantially potentiated by abundant LDL particles within the arterial wall (Gauderaut et al. 2012). Continuation of the scavenger process of macrophages and their growth due to consumption of further abundant LDL particles lead to their gradual change to resident macrophages and consequently to foam cells. Although this process might be primarily protective (for a temporarily increased inflow of cholesterol-carrying particles) in situations where there is long-lasting accelerated transport of LDL particles to the arterial wall (and more if these particles are oxidized within the subendothelium), it also leads to the growth of fatty streaks and further development of atherosclerosis and apoptosis of some foam cells which stimulate inflammation and proliferation of smooth muscle cells (Lussis 2000). Two other negative effects on atherogenesis have been documented: a decrease of activity of reverse cholesterol transport (Reiss and Cronstein 2012) and an increase of intravasal triglyceride concentration and their accumulation in macrophages of the arterial wall. Remnants of very low-density lipoprotein (VLDL) particles are able to enter the arterial wall and are scavenged in macrophages (Bojic et al. 2012). This process also stimulates production of proinflammatory cytokines and further worsens proinflammatory status within the arterial wall. This explains recently proven effect of postprandial triglyceride concentration on myocardial infarction mortality (Langsted et al. 2011).

\section{Perivascular adipose tissue}

Recently, a new possible atherogenic effect of 
adipose tissue surrounding large and middle size arteries has been described. Perivascular adipose tissue differs from other adipose tissue by the certain presence of brown adipocytes alongside their white variants (Szasz and Web 2012). It is more vascularized and displays different characteristics in different parts of the body (Chatterjee et al. 2009). Several laboratories have analyzed the possible effect of perivascular fat on vessel wall reactivity. Both positive (Rittig et al. 2008) as well as negative (Reifenberger et al. 2007) effects have been described. These differences of perivascular tissue influence on arterial wall reactivity may be mediated by free fatty acids released from adherent adipose tissue. Increased activity of triglyceride lipase furnishes free fatty acids directly to the arterial wall, which induces endothelial dysfunction. Contrary in experimental model of mouse without functioning lipase (triglyceride lipase KO) no endothelial dysfunction appeared (Zimmermann et al. 2009).

The negative effect of perivascular adipose tissue on atherosclerosis progression was described in a morphological analysis of 16 human hearts postmortem (Verhagen et al. 2012). An increased volume of adipose tissue surrounding atherosclerotic lesions of the coronary artery was found together with an increase of the tissue concentration of lymphocytes. An increased volume of perivascular adipose tissue was also found in patients with coronary atherosclerosis documented by computer tomography (Greif et al. 2009).

In contrast to the results of Greif, we did not find any difference in the volume of perivascular adipose tissue surrounding the coronary artery, when groups with (ischemic heart disease) and without atherosclerosis (dilation cardiomyopathy) were compared (Kralova Lesna et al. 2015). Conversely, we were able to find a correlation of monocyte infiltration of the coronary artery to macrophage content in surrounding adipose tissue in patients with ischemic heart disease, whereas no such type of correlation in patients transplanted for cardiomyopathy was found. It is questionable whether the accelerated deposit of ectopic fat surrounding the artery influences coronary atherosclerosis per se, or if some other environmental effects are at play. In a large epidemiological study - the Framingham Heart Study (Lehman et al. 2010) - the volume of perivascular adipose tissue correlated with several risk factors of atherosclerosis (BMI, waist circumference, total and visceral fat volume and fasting glycemia). This suggests that the apparent direct effect of PVAT might relate to other risk factors of cardiovascular disease and proinflammatory status. In our above-mentioned study, we document that the volume of PVAT depends on a change to BMI during the last two years before transplantation, irrespective of the original diagnosis for transplantation (ischemic heart disease or cardiomyopathy).

\section{Conclusion}

The two main atherogenic effects of enlarged ectopic adipose tissue are dyslipidemia and chronic proinflammatory status. The relationship of dyslipidemia to the acceleration of the atherogenic process has already been well documented and the causality of small LDL particles in this process has been proved. On the other hand, the effect of ectopic fat on atherogenesis due to proinflammatory status has not been discovered yet. The loss of immune regulation in obesity-associated adipose tissue has been found, but its atherogenic effect is still not understood and, of course, there is still no proof of causality. Several anti-inflammatory agent studies are underway but no results have been released. However, this does not mean that maintaining BMI in the desirable range and decreasing ectopic fat volume should not be very important issues for preventive cardiology.

\section{Conflict of Interest}

There is no conflict of interest.

\section{Acknowledgements}

This work was supported by the research project $\mathrm{MH} \mathrm{CZ}$ - DRO (Institute for Clinical and Experimental Medicine - IKEM, IN 00023001) and NT14009-3 of the Internal Grant Agency of the Ministry of Health of the Czech Republic.

\section{References}

ADIELS M, TASKINEN MR, PACKARD C, CASLAKE MJ, SORO-PAAVONEN A, WESTERBACKA J, VEHKAVAARA S, HÄKKINEN A, OLOFSSON SO, YKI-JÄRVINEN H, BORÉN J: Overproduction of large VLDL particles is driven by increased liver fat content in man. Diabetologia 49: 755-765, 2006. 
ADYA R, TAN BK, RANDEVA HS: Differential effects of leptin and adiponectin in endothelial angiogenesis. J Diabetes Res 2015: 648239, 2015.

BAYS HE: Adiposopathy is "sick fat" a cardiovascular disease? J Am Coll Cardiol 57: 2461-2473, 2011.

BOJIC LA, SAWYEZ CG, TELFORD DE, EDWARDS JY, HEGELE RA, HUFF MW: Activation of peroxisome proliferator-activated receptor $\delta$ inhibits human macrophage foam cell formation and the inflammatory response induced by very low-density lipoprotein. Arterioscler Thromb Vasc Biol 32: 2919-2928, 2012.

BOREN J, MATIKAINEN N, ADIELS M, TASKINEN MR: Postprandial hypertriglyceridemia as a coronary risk factor. Clin Chim Acta 431: 131-142, 2014.

BOULOUMIE A, MARUMO T, LAFONTAN M, BUSSE R: Leptin induces oxidative stress in human endothelial cells. FASEB J 13: 1231-1238, 1999.

BROWN MS, GOLDSTEIN JL: Lipoprotein metabolism in macrophage: implications for cholesterol deposition in atherosclerosis. Annu Rev Biochem 52: 223-261, 1983.

CHATTERJEE TK, STOLL LL, DENNING GM, HARRELSON A, BLOMKALNS AL, IDELMAN G, ROTHENBERG FG, NELTNER B, ROMIG-MARTIN SA, DICKSON EW, RUDICH S, WEINTRAUB NL: Proinflammatory phenotype of perivascular adipocytes: influence of high-fat feeding. Circ Res 104: 541-549, 2009.

COHEN JC, HORTON JD, HOBBS H: Human fatty liver disease: old questions and new insights. Science 332: 1519$1523,2011$.

COMBADIERE C, POTTEAUX S, RODERO M, SIMON T, PEZARD A, ESPOSITO B, MERVAL R, PROUDFOOT A, TEDQUI A, MALLAT Z: Combined inhibition of CCL2, CX3CR1, and CCR5 abrogates Ly6C(hi) and Ly6C(lo) monocytosis and almost abolishes atherosclerosis in hypercholesterolemic mice. Circulation 117: 1649-1657, 2008.

DIPIETRO L, KATZ LD, NADEL ER: Excess abdominal adiposity remains correlated with altered lipid concentrations in healthy older women. Int J Obes Relat Metab Disord 23: 432-436, 1999.

DONNELLY KL, SMITH CL, SCHWARZENBERG SJ, JESSURUN J, BOLDT MD, PARKS EJ: Sources of fatty acids stored in liver and secreted via lipoproteins in patients with nonalcoholic fatty liver disease. J Clin Invest 115: 1343-1351, 2005.

FERRANTE AW JR: The immune cells in adipose tissue. Diabetes Obes Metab 15 (Suppl 3): 34-38, 2013.

FU Y, MOORE XL, LEE MK, FERNÁNDEZ-ROJO MA, PARAT MO, PARTON RG, MEIKLE PJ, SVIRIDOV D, CHIN-DUSTING JP: Caveolin-1 plays a critical role in the differentiation of monocytes into macrophages. Arterioscler Thromb Vasc Biol 32: e117-e125, 2012.

GAUDREAULT N, KUMAR N, POSADA JM, STEPHENS KB, REYES DE MOCHEL NS, EBERLÉ D, OLIVAS VR, KIM RY, HARMS MJ, JOHNSON S, MESSINA LM, RAPP JH, RAFFAI RL: ApoE suppresses atherosclerosis by reducing lipid accumulation in circulating monocytes and the expression of inflammatory molecules on monocytes and vascular endothelium. Arterioscler Thromb Vasc Biol 32: 264-272, 2012.

GOLDSTEIN JL, BROWN MS: Regulation of LDL receptors: implication for pathogenesis and therapy of hypercholesterolemia and atherogenesis. Circulation 76: 504-507, 1987.

GREIF M, BECKER A, VON ZIEGLER F, LEBHERZ C, LEHRKE M, BROEDL UC, TITTUS J, PARHOFER K, BECKER CH, REISER M, KNEZ A, LEBER AW: Pericardial adipose tissue determined by dual source CT is a risk factor for coronary atherosclerosis. Arterioscler Thromb Vasc Biol 29: 781-786, 2009.

GUPTA S, PABLO AM, JIANG XC, WANG N, TALL AR, SCHINDLER C: IFN- $\gamma$ potentiates atherosclerosis in ApoE knock-out mice. J Clin Invest 99: 2752-2761, 1997.

ITALIANI P, BORASCHI D: From monocytes to M1/M2 macrophages: phenotypical vs. functional differentiation. Front Immunol 5: 514, 2014.

KAWANAMI D, MAEMURA K, TAKEDA N, HARADA T, NOJIRI T, IMAI Y, MANABE I, UTSUNOMIYA K, NAGAI R: Direct reciprocal effects of resistin and adiponectin on vascular endothelial cells: A new insight into adipocytokine-endothelial cell interactions. Biochem Biophys Res Commun 314: 415-419, 2004.

KERSHAW EE, FLIER JS: Adipose tissue as an endocrine organ. J Clin Endocrinol Metab 89: 2548-2556, 2004. 
KRALOVA LESNA I, TONAR Z, MALEK I, MALUSKOVA J, NEDOROST L, PIRK J, PITHA J, LANSKA V, POLEDNE R: Is the amount of coronary perivascular fat related to atherosclerosis? Physiol Res 64 (Suppl 3): S435-S443, 2015.

LANGSTED A, FREIBERG JJ, TYBJÆRG-HANSEN A, SCHNOHR P, JENSEN GB, NORDESTGAARD BG: Nonfasting cholesterol and triglycerides and association with risk of myocardial infarction and total mortality: the Copenhagen City Heart Study with 31 years of follow-up. J Intern Med 270: 65-75, 2011.

LEHMAN SJ, MASSARO JM, SCHLETT CL, O'DONNELL CJ, HOFFMANN U, FOX CS: Peri-aortic fat, cardiovascular disease risk factors, and aortic calcification: the Framingham Heart Study. Atherosclerosis 210: 656-661, 2010.

LIUZZI A, SAVIA G, TAGLIAFERRI M, LUCANTONI R, BERSELLI ME, PETRONI ML, DE MEDICI C, VIBERTI GC: Serum leptin concentration in moderate and severe obesity: relationship with clinical, anthropometric and metabolic factors. Inst J Obes Relat Metab Disord 23: 1066-1073, 1999.

LOHMANN C, SCHAFER N, VON LUKOWICZ T, SOKRATES STEIN MA, BOREN J, RUTTI S, WAHLI W, DONATH MY, LUSCHER TF, MATTER CM: Atherosclerotic mice exhibit systemic inflammation in periadventitial and visceral adipose tissue, liver, and pancreatic islets. Atherosclerosis 207: 360-367, 2009.

LUMENG CN, BODZIN JL, SALTIEL AR: Obesity induces a phenotypic switch in adipose tissue macrophage polarization. J Clin Invest 117: 175-184, 2007.

LUSIS AJ: Atherosclerosis. Nature 407: 233-241, 2000.

MALLAT Z: Macrophages. Arterioscler Thromb Vasc Biol 34: 2509-2519, 2014.

MANUEL-APOLINAR L, LÓPEZ-ROMERO R, ZARATE A, DAMASIO L, RUIZ M, CASTILLO-HERNÁNDEZ C, GUEVARA G, MERA-JIMÉNEZ E: Leptin mediated ObRb receptor increases expression of adhesion intercellular molecules and cyclooxygenase 2 on murine aorta tissue inducing endothelial dysfunction. Int $J$ Clin Exp Med 6: 192-196, 2013.

MARTINEZ FO, SICA A, MANTOVANI A, LOCATI M: Macrophage activation and polarization. Front Biosci 13: 453-461, 2008.

MATTU HS, RANDEVA HS: Role of adipokines in cardiovascular disease. $J$ Endocrinol 216: T17-T36, 2013.

MILLS CHD: M1 and M2 macrophages: oracles of health and disease. Immunology 32: 463-488, 2012.

MULDER R, BANETE A, BASTA S: Spleen-derived macrophages are readily polarized into classically activated (M1) or alternatively activated (M2) states. Immunobiology 219: 737-745, 2014.

ODEGAARD JI, RICHARDO-GONZALEZ RR, GOFORTH MH, MOREL CR, SUBRAMANIAN V, MUKUNDAN L, RED EAGLE A, VATS D, BROMBACHER F, FERRANTE AW, CHAWLA A: Macrophage-specific PPARgamma controls alternative activation and improves insulin resistance. Nature 447: 1116-1120, 2007.

PARK YM, FEBBRAIO M, SILVERSTEIN RL: CD36 modulates migration of mouse and human macrophages in response to oxidized LDL and may contribute to macrophage trapping in the arterial intima. J Clin Invest 119: 136-145, 2009.

POSTEA O, VASINA EM, CAUWENBERGS S, PROJAHN D, LIEHN EA, LIEVENS D, THEELEN W, KRAMP KB, BUTOI ED, SOEHNLEIN O, HEEMSKERT JW, LUDWIG A, WEBER C, KOENEN RR: Contribution of platelet $\mathrm{CX}(3) \mathrm{CR} 1$ to platelet-monocyte complex formation and vascular recruitment during hyperlipidemia. Arterioscler Thromb Vasc Biol 32: 1186-1193, 2012.

REAVEN GM: Syndrome X: 6 years later. J Intern Med Suppl 736: 13-22, 1994.

REIFENBERGER MS, TURK JR, NEWCOMER SC, BOOTH FW, LAUGHLIN MH: Perivascular fat alters reactivity of coronary artery: effects of diet and exercise. Med Sci Sports Exerc 39: 2125-2134, 2007.

REISS AB, CRONSTEIN BN: Regulation of foam cells by adenosine. Arterioscler Thromb Vasc Biol 32: 879-886, 2012.

RITTIG K, STAIB K, MACHANN J, BÖTTCHER M, PETER A, SCHICK F, CLAUSSEN C, STEFAN N, FRITSCHE A, HÄRING HU, BALLETSHOFER B: Perivascular fatty tissue at the brachial artery is linked to insulin resistance but not to local endothelial dysfunction. Diabetologia 51: 2093-2099, 2008.

SCOTT DW, CHEN J, CHACKO BK, TRAYLOR JG JR, ORR AW, PATEL RP: Role of endothelial N-glycan mannose residue in monocyte recruitment during atherogenesis. Arterioscler Throm Basc Biol 32: e51-e59, 2012. 
SHULMAN GI: Ectopic fat in insulin resistance, dyslipidemia, and cardiometabolic disease. $N$ Engl J Med 371: 1131$1141,2014$.

STOUT RD, SUTTLES J: Functional plasticity of macrophages: reversible adaptation to changing microenvironments. J Leukoc Biol 76: 509-513, 2004.

STÖGER JL, GOOSSENS P, DE WINTHER PJ: Macrophage heterogeneity: relevance and functional implications in atherosclerosis. Curr Vasc Pharmacology 8: 233-248, 2010.

SUGANAMI T, OGAWA Y: Adipose tissue macrophages: their role in adipose tissue remodeling. J Leukoc Biol 88: 33-39, 2010.

SZASZ T, WEBB RC: Perivascular adipose tissue: more than just structural support. Clin Sci (Lond) 122: 1-12, 2012.

TAYLOR PR, MARTINEZ-POMARES L, STACEY M, LIN HH, BROWN GD, GORDON S: Macrophage receptors and immune recognition. Ann Rev Immunol 23: 901, 2005.

VAGUE J: La differentiation sexuelle, facteur determinant des forms de l'obesite. Presse Med 55: 339, 1947.

VAN GILS JM, DERBY MC, FERNANDES LR, RAMKHELAWON B, RAY TD, RAYNER KJ, PARATHATH S, DISTEL E, FEIG JL, ALVAREZ-LEITE JI, RAYNER AJ, MCDONALD TO, O'BRIEN KD, STUART LM, FISHER EA, LACY-HULBERT A, MOORE KJ: The neuroimmune guidance cue netrin-1 promotes atherosclerosis by inhibiting the emigration of macrophages from plaques. Nat Immunol 13: 136-143, 2012.

VERHAGEN SN, VINK A, VAN DER GRAAF Y, VISSEREN FL: Coronary perivascular adipose tissue characteristics are related to atherosclerotic plaque size and composition. A post-mortem study. Atherosclerosis 225: 99-104, 2012.

WEISBERG SP, MCCANN D, DESAI M, ROSENBAUM M, LEIBEL RL, FERRANTE AW JR: Obesity is associated with macrophage accumulation in adipose tissue. J Clin Invest 112: 1796-1808, 2003.

XU H, BARNES GT, YANG Q, TANG G, YANG D, CHOU CJ, SOLE J, NICHOLS A, ROSS JS, TARTAGLIA LA, CHEN H: Chronic inflammation in fat plays a crucial role in the development of obesity-related insulin resistance. J Clin Invest 112: 1821-1830, 2003.

ZIMMERMAN R, LASS A, HAEMERLE G, ZECHNER R: Fate of fat: the role of adipose triglyceride lipase in lipolysis. Biochim Biophys Acta 1791: 464-500, 2009. 